\title{
Fabric of Devotion: William Quiller Orchardson's The Story of a Life and Women Religious in Victorian Britain
}

Ayla Lepine

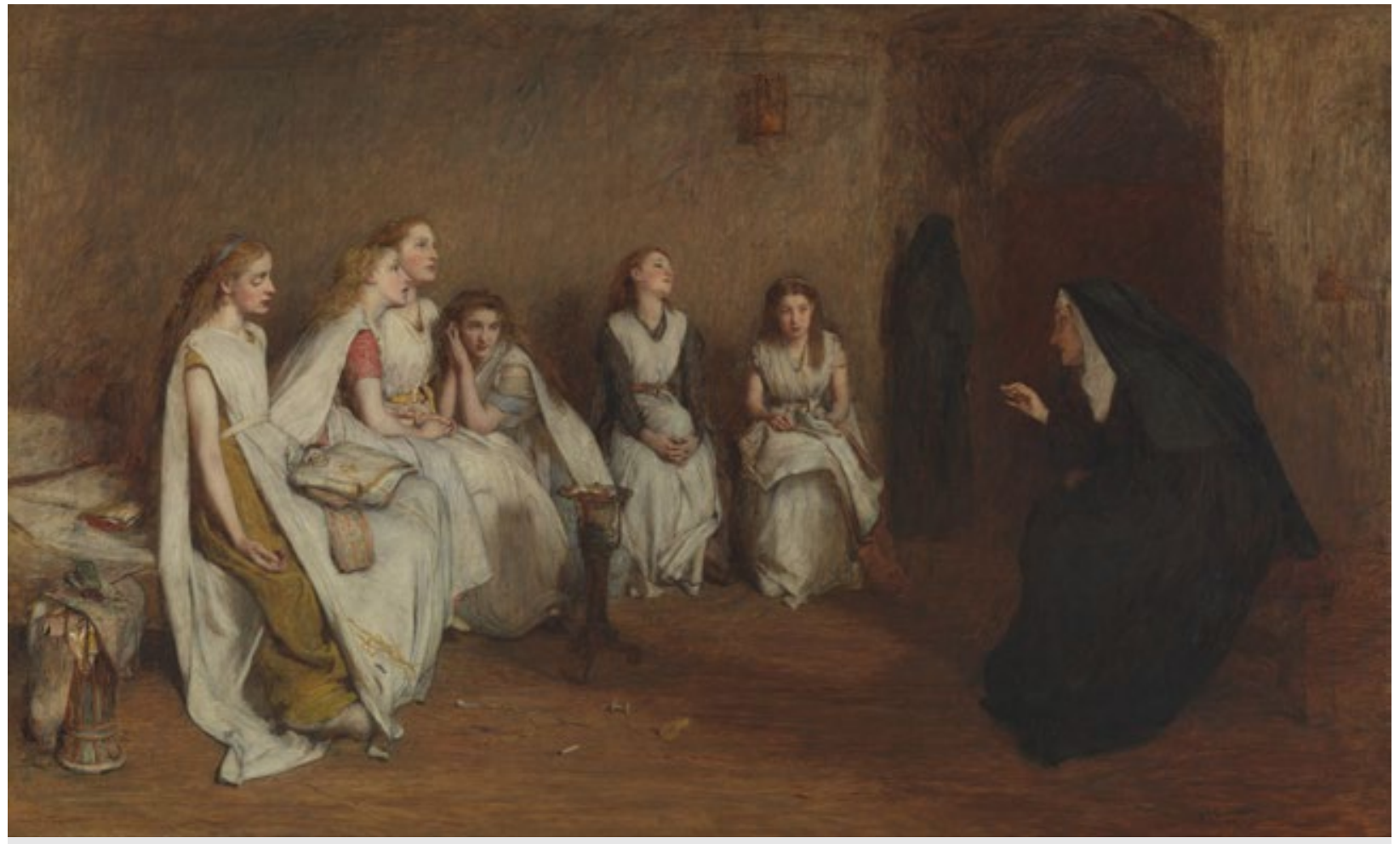

Fig. 1 William Quiller Orchardson, The Story of a Life, oil on canvas, 1866

Produced in a Christian tradition for the viewing pleasure of the London art world's cultured audiences, William Quiller Orchardson's The Story of a Life alludes to the controversies and contentions of religious life and women's roles in mid-nineteenthcentury Britain (Fig. 1). The Art Journal, an important Victorian publication focused on the arts in Britain and well known for its Royal Academy reviews, described Orchardson's painting as "the interior of a convent, where a nun with pale and saddened countenance appears to excite the sympathy of a number of young novitiates by the story of her life." Completed in 1866 and exhibited at the Royal Academy the same year, the painting draws us into an ambiguous space where holiness and penitence meet quotidian labor and the implied dangers of the modern London metropolis for young women. Although Orchardson's painting may at first seem to make a strong statement about the role of women's monasticism in the early Victorian era, ultimately the painting is less a serious engagement with debates around this topic than it is an opportunity for Orchardson to build his career as a painter. Engaging with growing public curiosity regarding the resurgence of religious communities for women, Orchardson brought this theme into contact with his own distinctive perspective on the depiction of dramatic emotion. By depicting a popular, somewhat titillating and enigmatic view into a female homosocial realm typically forbidden to male viewers, Orchardson played into the art 
world's desire for engaging theatrical fantasies about feminine space.

In 1862, Orchardson had moved from Scotland to London to develop his career. He began to exhibit at the Royal Academy in the 1860 s and became an Associate of the Academy later that decade. The Story of a Life appeared in these first crucial years of reputation building. ${ }^{2}$ The painting is large; akin to the late Victorian "problem picture," its compelling narrative invites viewers to puzzle out its social connotations and possibilities. Orchardson became a master of this genre. As the art historian Pamela Fletcher points out, this type of painting was characterized by "narrative, moral and psychological ambiguities" that left their audiences guessing. ${ }^{3}$ This category of visual culture in Britain emerged towards the end of the Victorian period, and, as early as the 1860s, Orchardson was one of its key progenitors with works like The Story of a Life. As Fletcher argues, Orchardson's practice evolved from narrative painting towards increasingly ambiguous emotional and psychological territory. The Story of a Life was a turning point, by far his most emotionally uneasy and uncertain artwork to date.

The action of The Story of a Life takes place within a murky zone constructed through an economical palette, in which the singing hues of multiple embroidery threads and the glistening gold of a series of different types of ecclesiastical vestments are picked out against the girls' simple clothing and the surrounding ruddy shadows. A nun in a Benedictine black habit with white wimple gestures towards a group of young women, gazing at them intently. Their reactions to her tale vary considerably; the image is a study in emotional complexity. Though numerous reviewers in the Victorian art press suggested the girls were novices, in order to be so their habits would have been black with a white veil. Instead, these young women wear simple white scapular-like tunics tied loosely over their own clothing, suggesting they are most likely girls taken temporarily into the care of the convent, but not necessarily committed to a nun's life. This practice was common; they would have learned practical skills in the community before returning to London's secular space within months. ${ }^{4}$

Orchardson's scene conflates a space of work with a more domestic one, and places the girls in contact with professed nuns in a manner closer to that of an ad hoc classroom than a workroom for embroidery. Arranged in a loose arc, bright textiles at varied stages of completion lie unattended in the girls' laps, their multi-colored threads dangling in anticipation of being picked up again and transformed into tight stitching when the nun's story ends. The embroidery the girls have been sewing appears to be a number of different types of Christian liturgical textiles; they may be stoles, chasubles, and perhaps even a humeral veil used at the liturgy of Benediction, in which a consecrated wafer is venerated on the altar and raised by a priest in a monstrance in order to bless the congregation. Orchardson's familiarity with Victorian embroidery practices in convents may have been limited, but he had ample access to historic ecclesiastical embroidery at the South Kensington museum, which he visited frequently when researching his complex paintings of historical subjects. ${ }^{5}$

Orchardson's Story of a Life is by no means a documentary study of domestic and labor practices within institutions run by women religious. Nonetheless, Orchardson's 
inclusion of ecclesiastical textiles may have been a deliberate choice, intended to suggest an Anglican setting for the painting and thus reference contemporary controversies regarding the growth of convents and nuns' organizations in the Church of England. ${ }^{6}$ In the painting, the nuns' habits, as they are Benedictine, could mark them either as Anglican or Roman Catholic. The practice of embroidery, however, and working with young women to produce embroidery, was more widespread among Anglican sisterhoods than in Roman Catholic convents.

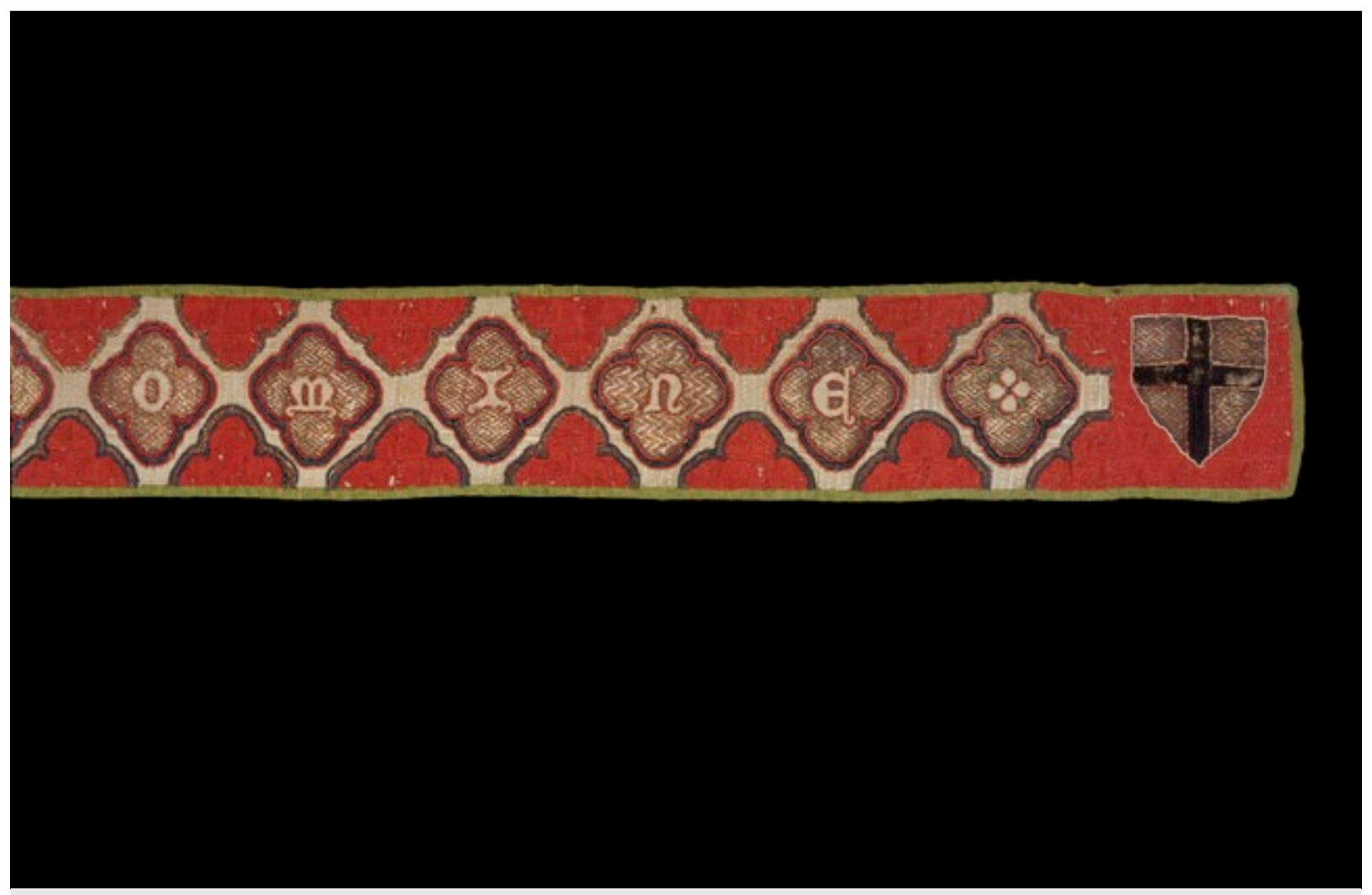

Fig. 2 Sister Joan of Beverly, frontal band, linen embroidered in silks and silver gilt, early 14th century

In Anglican sisterhoods the revival of Opus Anglicanum-English embroidery prized in the Middle Ages for its intricacy and fineness-was at the heart of their livelihood and expression of religious identity through neo-medieval material culture (Fig. 2). ${ }^{7}$ Sisterhoods such as the Society of Saint Margaret and the Society of All Saints Sisters of the Poor produced intricate embroidered textiles that would be used as altar frontals, chasubles, and copes in High Anglican sanctuaries (Fig. 3) ${ }^{8}$ Both sisterhoods founded central London embroidery schools in the late 1850 os and early 1860 s with strong connections to artists and architects in Orchardson's circle. In this period nuns were increasingly visible in the fabric of Victorian society and yet their very presence, as they also lived together in community and participated in a life devoted to God behind closed doors, amplified their status as a mysterious one.

The nun was a polyvalent figure in Anglican and Catholic religious life in Britain. ${ }^{9}$ On the one hand, these non-normative women's organizations offered women opportunities for social reform through labor, devotion, and the production of art and even architecture. ${ }^{10}$ 
As Susan O’Brien has illuminated, “Taking the veil, contrary to contemporary popular belief, meant the beginning not the end of a useful life."11 On the other hand, numerous prominent Christian voices in mid-nineteenth-century Britain from the Evangelical wing of the Church of England were concerned about the rise in numbers of Anglican nuns. For some, these nuns were a perplexing combination of virginal purity and the very antithesis of ideal womanhood, as they were not wives and mothers. In 1863 the Christian Socialist F. D. Maurice wrote passionately "there is a power committed to women, to all in different measures, of which they have no right to deprive the world; from the loss of which all society must suffer." ${ }^{12}$

This growth of female religious communities came in 1829 in the wake of Catholic Emancipation (a gradual reduction of restrictions on British Catholics over the course of the late-eighteenth and early-nineteenth centuries) and the emergence of the Oxford Movement and its associated revival of medieval theological and visual culture for Anglicanism..$^{13}$ John Henry Newman, E. B. Pusey, John Keble, and members of their circle initiated the Oxford Movement in the 1830s. Both priests and academics, these key Anglican cultural figures wrote polemical theological tracts (indeed, followers of the movement were also known as Tractarians) that emphasized a renewed interest in the Church Fathers and pre-Reformation Church identity and practice. ${ }^{14}$

Although some within the Church of England accused Tractarians of offering a position too close to that of Roman Catholicism, the Oxford Movement's ideas helped inspire a revival of female monastic life. Indeed, several of its founders actively promoted female monasticism: Pusey founded and supported Anglican sisterhoods, and, as early as 1835, Newman wrote positively about convents as part of a possible future for the Church of England, following Roman Catholic example:

As matters stand, marriage is the sole shelter which a defenseless portion of the community has against the rude world; whereas foundations for single females, under proper precautions, at once hold out protection to those who avail themselves of them, and give consideration to the single state itself, thus saving numbers from the temptation of throwing themselves rashly away upon unworthy objects, transgressing their sense of propriety, and embittering their future life. ${ }^{15}$

By 1839, allies in art and architecture joined the Oxford Movement. They were keen to connect these ideas with the cultural phenomenon of the Gothic Revival. ${ }^{16}$ The Ecclesiological Society was the most successful and well known of these groups, advocating for Oxford Movement views and new Gothic art, architecture, and neomedieval music. ${ }^{17}$ Their influential journal, The Ecclesiologist, contained reviews and critical essays written by leading figures in this new form of Anglicanism alongside texts by significant Victorian architects including William Burges and G. F. Bodley. ${ }^{18}$ Since the establishment of the 1830 s phase of the Oxford Movement, the founder-Tractarian John Henry Newman had been an active and controversial voice in the Church. He converted from Anglicanism to Roman Catholicism in 1845, and his influential spiritual autobiography Apologia Pro Vita Sua was published in $1866 .{ }^{19}$ Moreover, in the 1860 , 
followers of the Oxford Movement published a number of manuals for High Church ritual and liturgy, including Charles Walker's The Ritual Reason Why in $1866 .{ }^{20}$ As a result of this movement, a spirit of "High Anglicanism," also known as Ritualism or Anglo-Catholicism, took hold in the first decades of Queen Victoria's reign. Its importance was such that Orchardson and his network of painters and patrons would have been well aware of its impacts.

Victorian debates regarding the renewed prominence of Anglican and Roman Catholic nuns in British public and private life fueled mid-to-late-nineteenth-century neomedieval depictions of female monastic life. Indeed art historian Susan Casteras has identified 50 paintings depicting nuns that were exhibited at the Royal Academy between the 1830 s and 1860 s. It was a relatively familiar subject-though no more than one or two were present on the walls in a single year-for the British art-viewing public. ${ }^{21}$

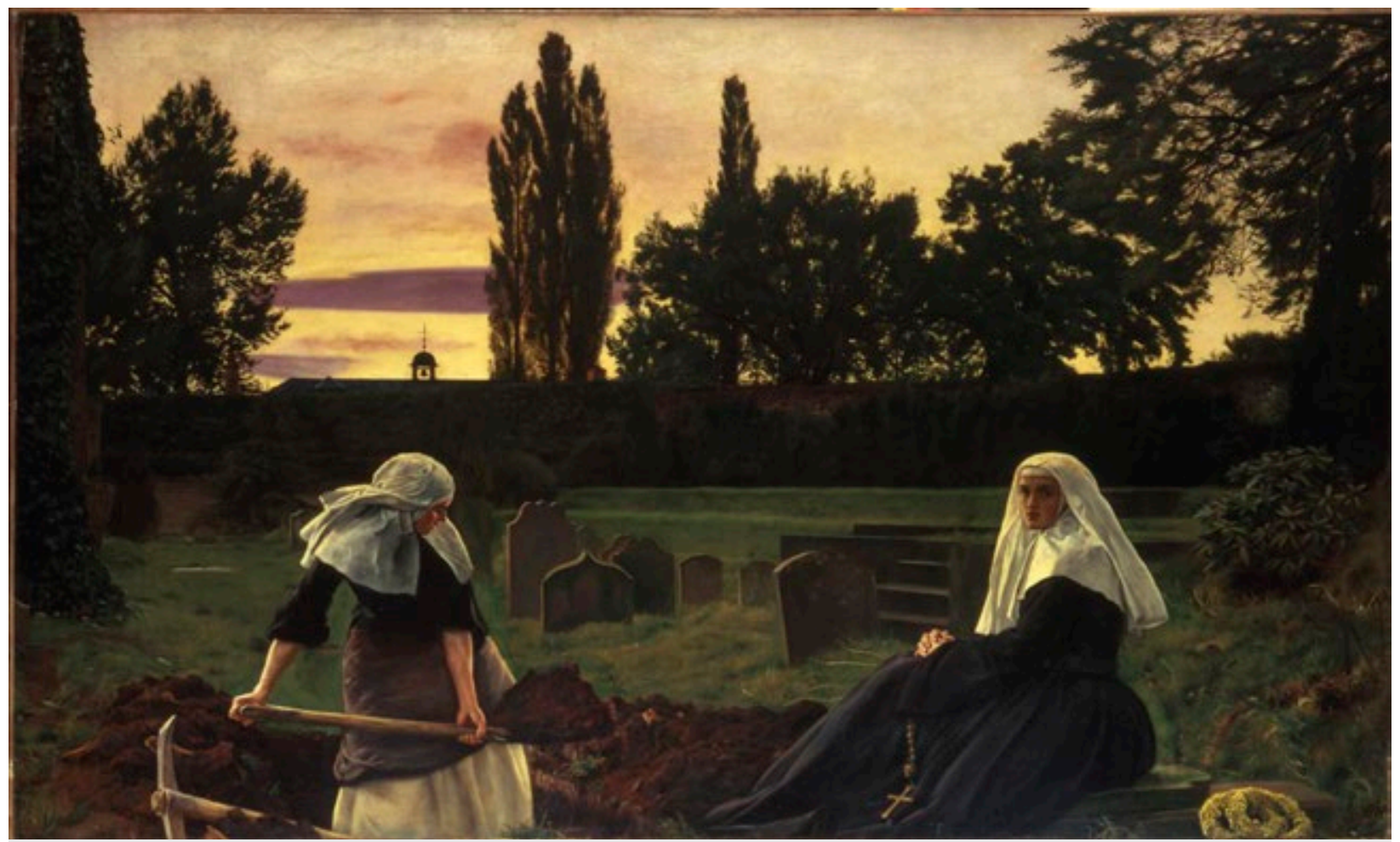

Fig. 3 Sir John Everett Millais, Vale of Rest, 1858-59

Fascination with women religious was particularly evident in Pre-Raphaelite work, such as Charles Allston Collins's Convent Thoughts (1850-51) and John Everett Millais's Vale of Rest (1858-59). These paintings reflect some of the diversity of Victorian responses to women religious. In Millais's Vale of Rest, the drama is less one of sensuality than of dark emotional ambiguity. Two nuns labor to dig a grave in a secluded churchyard, sleeves rolled up and shovel pressing into the earth, against the backdrop of an orangetinged evening sky. In Collins's painting, a solitary nun in white holds open the pages of an illuminated prayer book, exposing an image of the crucifixion while her other hand gently grasps the stem of a passion flower. The flower, symbolic of the Passion of Christ, 
suggests the nun's contemplation of Christ's rejection, torture, entombment, and death, and of the mourning of Christ's followers prior to his resurrection.

In contrast, Orchardson's The Story of a Life is less preoccupied with questions of the Passion and the afterlife than with visually conveying the relationship between work, the body, and the potential for $\sin ^{22}$ Though no text was shown alongside the painting at the Royal Academy in 1866, there is a handwritten poem titled "The Story of a Life" affixed to the canvas's wooden stretchers, signed "F. E. W." It cannot be known for sure, but these may be the initials of the painter Frederick Walker. Orchardson and Walker knew one another well; indeed, in 1870 they shared lodgings for several months in Venice. ${ }^{23}$

The poem's perspective is also the viewer's, who voyeuristically gazes upon the girls and their storyteller, drawn into the drama:

\author{
They sat with Sister Monica, within the convent wall, \\ They heard not e'en the echo of the city trumpet's call \\ For, as they traced the silken flow'rs and drew the golden thread, \\ She told the story of her life, and of a love long dead. \\ They see her with her lover, in a moonlit garden stand, \\ And he bends him low and kisses her trembling little hand \\ 'O my children,' she is saying, and her voice is like a dream, \\ 'Trust not the light that men call love; 'tis but a phantom gleam'
}

The nun implores the girls to consider Christ as the only source of true peace and true love, not Victorian men and the pressures and tragedies of love in the world outside the convent. The poem's remaining stanzas describe the reaction of each girl who listens to the nun's story, with a wide emotional range. One "trembling, sadly cries," another determines to "win the golden prize of love" come what may, and another focuses on the promises of motherhood. ${ }^{24}$ In the anonymous poem, none of the girls who sew and listen indicates through her reaction that she intends to stay within the convent's walls. Both poem and painting refuse to offer a conclusive end to the "story" of the two nuns or the girls whose needlework lay idle as they listened to the sad narrative of lost love.

Orchardson's representation of nuns and girls in this shadowy interior is of central importance in considering the painter's wider interest in gender relations and narrative. A smaller version of the Yale Center for British Art's painting is at the Wolverhampton Art Gallery. ${ }^{25}$ It measures 58.5 x $94 \mathrm{~cm}$, making it approximately a third smaller than the Yale version, whose dimensions are $94 \times 153 \mathrm{~cm}$. The key difference between the two versions is in the way Orchardson handled the interior space. In the Wolverhampton painting, a crucifixion sculpture-a kind of rood that would normally be seen in a church at the threshold between nave and chancel-is located at the outer perimeter of the interior near the nun whose back is turned away from the viewer. Overall the scheme is somewhat lighter and the elements of the strange interior-neither church nor parlor nor workroom nor bedroom-are more visible. The palette is brighter and the painting 


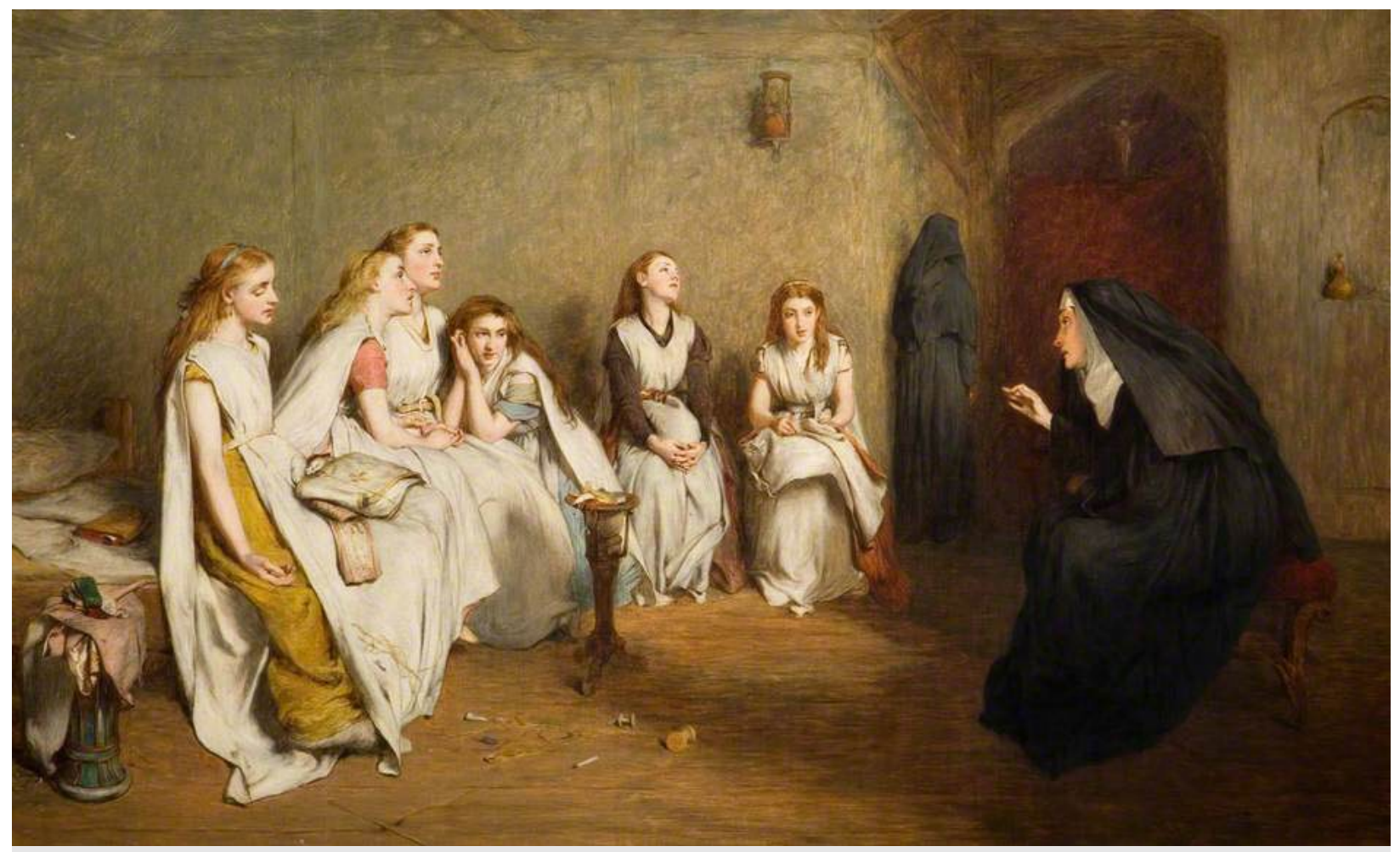

Fig. 4 William Quiller Orchardson, The Story of a Life, 1840-1910

style is somewhat looser. The shadowy figure of the nun with her back to the rest of the group is far more easily discerned against the lighter tones of the taupe walls, as is the crucifix which marks the distance, apparently suspended above a deep red curtain.

In contrast, the larger Yale painting's delicately worked surface and darker tone result in a more intimate space and a deeper sense of emotional intensity between the nun regaling the young girls with her tale and the girls themselves. The contrast between the dark room with its obscuring shadows and the bright tones of the girls' dresses and faces amplifies the sense of tension and draws the viewer in to witness the nun's story. The darker interior also generates suspense and surprise, as the black-habited body of the nun with her back to the viewer is not immediately apparent. Patient looking is not rewarded with clarity regarding the nun's narrative or the girls' reactions and identities. Instead it yields a further puzzle in the form of this dark and even ghostly second figure who turns to depart the room into an ambiguous shadowy alcove, rather than the Wolverhampton version's more distinctly sacred space marked by an image of the suffering God.

Despite the painting's focus on contemporary controversies, it is noteworthy that this was not the aspect of the work that critics commented on. The Story of a Life was No. 262 at the Royal Academy's exhibition in 1866. The critic for The Athenaeum described Orchardson's characterization and the emotional immediacy of the faces in The Story of a Life as "startling," and wrote, "if the novices were less miserable in their appearance ... the picture would be still more effective than it is. Mr. Orchardson, although seldom elaborate in his manner of working, has invariably so strong and vivid a conception 
of his subjects, that he never fails to make his works interesting...They fascinate the observer who may not see, or care to know, how flimsy is the execution of such potent ideas and telling designs." ${ }^{26}$ Orchardson's loose brushwork seems to have been particularly irksome for some who reviewed The Story of a Life during its exhibition at the Royal Academy. The Art Journal complained that "the picture is without color, and the execution is ragged and even slovenly." ${ }^{27}$ The general consensus amongst the critics' mixed reactions to Orchardson's 1866 exhibit was that the painting achieved a moderate level of emotional complexity and audience engagement; notably, no critic was shocked or the concern with lost love and Victorian femininity in relation to religious experience.

Orchardson, then, seemed to give the public what they desired; his work was in line with Royal Academy audience's overall taste for narrative paintings-the protoproblem picture. Although the painting's explicitly religious content engaged with the controversies of the 1860 s, Orchardson's preoccupation with emotional tension is just as evident in his theatrical paintings of literary and genre subjects. The Story of a Life's focus on young women and morality was a variation on a theme rather than a striking avant-garde departure from Orchardson's general practice. This painting offers a visual statement about late Victorian conceptions of femininity and sexuality within a religious framework and contributes to our understanding of period religious politics around women. Despite working in a milieu charged by controversies about women's monasticism, Orchardson was not making a specific statement regarding the increasing numbers of nuns in Victorian Britain per se. He was creating an emotive homosocial scene that drew on one of the key themes of his day, attempting to advance his painting career by producing a fantasy of theatrical dialogue in a world of devout working women and their youthful charges.

(C) Ayla Lepine

\section{Citation Guide}

1. Ayla Lepine, "Fabric of Devotion: William Quiller Orchardson's The Story of a Life and Women Religious in Victorian Britain," Essay, in Conversations: An Online Journal of the Center for the Study of Material and Visual Cultures of Religion (2015), doi:10.22332/con.ess.2015.3

Lepine, Ayla. "Fabric of Devotion: William Quiller Orchardson's The Story of a Life and Women Religious in Victorian Britain." Essay. In Conversations: An Online Journal of the Center for the Study of Material and Visual Cultures of Religion (2015). doi:10.22332/con.ess.2015.3

\section{Notes}

1. Art Journal (1870), 234. 
2. See Walter Armstrong, The Art of William Quiller Orchardson (London: Seeley and Co., 1895); Mary Cowling, “Orchardson, Sir William Quiller (1832-1910),” Oxford Dictionary of National Biography, Oxford University Press, 2004; online edition, Oct 2008 [www.oxforddnb.com/view/article/35324, accessed 21 Sept 2012]

3. Pamela Fletcher, Narrating Modernity: The British Problem Picture, 1895-1914 (Aldershot: Ashgate, 2003), 5 .

4. See Susan Mumm, Stolen Daughters, Virgin Mothers: Anglican Sisterhoods in Victorian Britain (Leicester: University of Leicester Press, 1999).

5. Sir William Quiller Orchardson, RA (Edinburgh: Scottish National Gallery, 1982), np

6. Mary Schoeser, English Church Embroidery, 1833-1953 (London: Watts and Company, 1998)

7. See Kathryn Rudy and Barbara Baert, eds., Weaving, Veiling and Dressing: Textiles and Their Metaphors in the Late Middle Ages (London: Brepols, 2007)

8. Mary Schoeser, English Church Embroidery, 1833-1953 (London: Watts and Company, 1998), 94-125; Peter Anson, The Call of the Cloister (London: SPCK, 1964).

9. See Mumm, Stolen Daughters, 1999; Carmen Mangion, "Women, Religious Ministry and Female Institution Building," in Sue Morgan and Jacqueline de Vries, eds., Women, Gender and Religious Cultures in Britain, 1800-1940 (London: Routledge, 2010), 7293 .

10. See A. Lepine, "At the Threshold: Victorian Ecclesiastical Textiles and Religious Orders," in Jane de Gay, ed., Victorian Spiritualities (Leeds: Leeds Centre for Victorian Studies, 2012), 3-13.

11. Susan O’Brien, “Terra Incognita: The Nun in Nineteenth-Century England,” Past \& Present 121 (Nov., 1988), 116

12. F. D. Maurice, "On Sisterhoods," The Victoria Magazine 1 (August 1863), 300.

13. See Stewart Brown and Peter Nockles, The Oxford Movement: Europe and the Wider World 1830-1930 (Cambridge: Cambridge University Press, 2012).

14. "Church Fathers" refers to saints and theologians from the first centuries of Christianity.

15. John Henry Newman, "Letters on the Church of The Fathers," British Magazine 6 (June 1835), 667.

16. See Owen Chadwick, The Victorian Church, 8 Vols (London: Adam and Charles 
Black, 1961); Geoffrey Rowell, The Vision Glorious: Themes and Personalities of the Catholic Revival in Anglicanism (Oxford: Clarendon, 1991).

17. See Nigel Yates, Anglican Ritualism in Victorian Britain, 1830-1910 (Oxford: Oxford University Press, 1999).

18. See G. F. Bodley, “Church Restoration in France: A Communication,” The Ecclesiologist 22 (1861), 70-78.

19. Ian Ker, "Newman, John Henry (1801-1890)," first published 2004; online edn, May 2011. doi:10.1093/ref:odnb/20023 [accessed 15 December 2015]

20. Charles Walker, The Ritual Reason Why (London: Hayes, 1866).

21. Susan Casteras, "Virgin Vows: The Early Victorian Artists' Portrayal of Nuns and Novices," Victorian Studies, 24, no. 2 (Winter 1981), 184.

22. For an explication of work and religious themes in Pre-Raphaelite art, see Tim Barringer, Men at Work: Art and Labour in Victorian Britain (London: Yale University Press, 2005), 21-82. For an extended discussion of representations of women as laborers in Victorian genre painting, see Kristina Huneault, Difficult Subjects: Working Women and Visual Culture in Britain, 1880-1914 (Aldershot: Ashgate, 2002).

23. Sir William Quiller Orchardson, RA (Edinburgh: Scottish National Gallery, 1982), np

24. F. E. W., "The Story of a Life," Yale Center for British Art.

25. William Quiller Orchardson, The Story of a Life, 1866 perma.cc/NFS3-KWXZ [accessed 10 May 2015]

26. The Athenaeum 1, 12 May 1866, 639.

27. The Art Journal, 1 June 1866, 168.

\section{Yale}

